\title{
Working Toward More Engaged And Successful Accounting Students: A Balanced Scorecard Approach
}

Amy Fredin, Ph.D., CPA (inactive), St. Cloud State University, USA

Peter Fuchsteiner, JD, CPA (inactive), St. Cloud State University, USA

Kris Portz, Ph.D., CPA (inactive), St. Cloud State University, USA

\begin{abstract}
Prior research indicates that student engagement is the key to student success, as measured by college grades, degree completion, and graduate school enrollment. We propose a set of goals and objectives for accounting students, in particular, to help them become engaged not only in the educational process, but also in the accounting profession. Utilizing a balanced scorecard framework, we categorize these goals into three main perspectives: Learning and Growth, Student Professional Development, and Employer/Graduate School. The proposed goals are related to each other, suggesting that accounting students recognize the wide reach of their experiences. If students are able to see that their successful completion of coursework can lead to successful interactions with business professionals (i.e. potential employers), they will be more likely to work hard in their endeavors - in other words, they will be more engaged in the broader educational experience. If they are more engaged in their educational experiences, they will be more likely to succeed.
\end{abstract}

Keywords: Balanced Scorecard; Student Success; Student Engagement; Accounting Majors

\section{INTRODUCTION AND LITERATURE REVIEW}

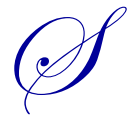

tudent success can be predicted by a number of factors, as explained by Kuh et al. (2006) in their comprehensive review of the literature as commissioned for the National Symposium on Postsecondary Student Success: Spearheading a Dialog on Student Success. Their report considered multiple theoretical perspectives on student success in college and cited over 650 articles in their effort to shed light on the critical issues underlying a student's success in college. Notable factors include: student background characteristics such as gender, race and ethnicity; precollege experiences such as socioeconomic status, academic preparation, and motivation to learn; enrollment patterns such as full-time or part-time status, 2-year or 4-year institutions, and direct or delayed enrollment. Other institutional factors play a role in a student's success, including emphasis on the first college year, academic support programs, active learning, and high standards and expectations for student performance, to name a few.

Once students start college a key factor in their success is student engagement. According to Kuh et al. (2006), student engagement is central to a student's success as it ties together student behaviors and institutional conditions. Student engagement represents not only the resources and approaches the institution utilizes to induce students to participate in worthwhile activities, but it is also the time and effort students put forth in their studies and other educational activities.

The link between student engagement and desired outcomes of college is well documented. We have chosen to take an even more focused and in-depth view of student engagement because this is where we, as faculty members and advisors, can make a difference. Kuh et al. (2006) note that many students enter college with uninformed expectations that differ substantially from those of faculty. Further, more and more students appear to be entering college already disengaged from the learning process (McCarthy and Kuh, 2006; NSSE 2005). If we 
can provide a communication tool to help students not only maneuver through their major course of study but also understand the vast interconnectedness of their overall educational experience, we believe that students will have a greater chance of success. With the dismal graduation rates (less than $50 \%$ of entering college students do not graduate) recently being reported for incoming students overall, the need for this type of communication tool is clear (Carey, 2004; Knapp, Kelly-Reid, and Whitmore, 2006; Bowen, Chinqos, and McPherson 2009).

Given our backgrounds in accounting, and given our experiences with students in this major program of study, we have seen our fair share of successes and failures. Would some students have been successful had they had a better 'roadmap' to help them through the major? That is, of course, difficult to say. Would a better 'roadmap' have made the road less difficult? Most likely. We have chosen to create a student engagement-success communication tool within a balanced scorecard framework, as the use of balanced scorecards has been shown to enhance not only communication between different levels of employees, but also employee engagement (Storey, 2002; Michalska, 2005; Bieker, 2003). We apply these prior findings from professional settings to an academic setting expecting that, with increased communication between students and faculty regarding their expectations will come increased student engagement, leading to greater success for these students.

\section{A BALANCED SCORECARD FOR ACCOUNTING STUDENT SUCCESS}

Balanced scorecards have been used in a variety of settings for years in order to bridge an organization's strategy with measurable steps and action items that employees can readily work toward. Balanced scorecards, if created according to Kaplan and Norton's vision (1992; 2001), should possess the following characteristics:

- Include a balance of measures from different perspectives to represent a more complete view of performance;

- $\quad$ Recognize key objectives, measures, targets and initiatives, that reflect the organization's overarching strategy;

- $\quad$ Build from one perspective to the next, such that success in more foundational areas lead to success in later/higher perspectives;

- Include a feedback loop, or learning loop, to allow users to revisit the hypothesized relationships within the scorecard, if changes or adjustments are needed.

As Kaplan and Norton (1992, 2001) describe, a balanced scorecard is a comprehensive performance measurement tool. This measurement tool should capture the key goals and objectives of an organization by weaving them into appropriate perspectives, such that one foundational perspective leads to a subsequent perspective. Not only are the goals and objectives identified in a scorecard, however. Specific targets or measures are noted for each objective, along with detailed initiatives or action items suggested to reach a target for these measures.

In a traditional balanced scorecard, for example, a 'Learning and Growth' perspective is considered foundational to an organization's success. It would capture measures associated with hiring the best people, training existing employees, and employee satisfaction, for example. Success in this 'Learning and Growth' perspective should lead to success in the next perspective, which is typically 'Internal Business Process', where objectives such as reducing lead time, increasing efficiency, and reducing defects would be measured. Success in the 'Internal Business Process' perspective would then lead to success in the 'Customer' perspective, which would lead to success in the 'Financial' perspective. The interconnectedness of the objectives from each perspective is a key tenet to the balanced scorecard. Hypothesized relationships between the organization's goals, which should be tied directly to the organization's strategy, should be identified.

A balanced scorecard type of performance measurement/strategy management system has proven to help numerous organizations improve their performance and has been utilized by businesses of virtually all sizes and from all industries, extending to governmental organizations and not-for-profit organizations (Kaplan and Norton, 2001; Niven, 2003). A Balanced Scorecard Institute has even been established to help organizations make progress along these lines (www.balancedscorecard.org). Colleges and universities have also adapted the balanced scorecard to help them manage their goals and objectives, which are, namely, to attract and appropriately serve their target 
student base (Beard, 2009; Karathanos and Karathanos, 2005; Cullen et al., 2003) and to evaluate faculty teaching performance (Hughes II and Pate, 2013).

Our development of a balanced scorecard for accounting student success merely extends the prior use of this tool to a more specific audience. Given that an accounting degree is reportedly more rigorous than other business majors, but one that provides a clear path to employment and long-term career stability, (Scarpati and Johnson, 2012) we think this is a good place to start. The individual objectives, measures, targets, and initiatives included in our scorecard for accounting student success represent intermediate aspects of success that prior researchers have identified as important (Kuh et al., 2006; Andrews and Higson, 2008; Arquero-Montano et al., 2001; Fallows and Stevens, 2000; Gammie and Gammie, 2002; Hassall et al., 2005; Kavanagh and Drennan, 2008; de Villiers, 2010; Violette and Chene, 2008; Cory and Pruske, 2012).

The balanced scorecard framework represents a comprehensive view of performance - in this case, student performance. While a mere checklist of courses and program requirements may communicate the demands of an accounting program to some students, it completely neglects the interconnectedness of these components. Further, it does not require the student to recognize how important their engagement is to the success of their educational pursuit. A balanced scorecard can address virtually all aspects of an undergraduate degree in accounting (or any other area of study, for that matter), by bridging a student's ultimate goal - to graduate with an accounting degree and obtain a full-time position in the field, or to continue further study by being accepted into a graduate degree program - with the underlying components that will be necessary stepping stones in order to achieve that goal.

In order for students to have a more tactical plan to reach their ultimate goal, we established a balanced scorecard framework (see Appendix A), where more specific details have been identified to help students find a way to accomplish their goals. Adapting Kaplan and Norton's (1992) design, we have included three perspectives in our framework: learning and growth perspective, student professional development perspective, and employer/graduate school perspective. Objectives, measures, targets, and initiatives are included for each perspective based on not only Kuh et al.'s (2006) general conclusions for student success, but also on additional resources specifically related to accounting student success.

\section{Learning and Growth Perspective}

In the most foundational perspective, Learning and Growth, the key goals identified include:

- Successfully complete coursework (first the foundational courses such as intermediate accounting, then other required courses such as audit and tax, and finally the elective courses);

- $\quad$ Develop and use technology skills; and

- $\quad$ Develop and use organizational skills;

- $\quad$ Get involved on- and off-campus.

As Kuh et al. (2006) recognize in their comprehensive review, grades are an important predictor of a student's subsequent academic success and likelihood of completing a degree. In fact, Pascarella and Terenzini (2005) conclude that grades are most likely the best predictor of student success (as measured by degree completion and graduate school enrollment). They further note that grades in the first year are particularly predictive of future academic success, while the strength of grades as an indicator of success diminishes slightly each subsequent year. These findings support our placement of 'successful completion of coursework' in the most foundational perspective of the scorecard.

A second objective included in the foundational perspective of our scorecard is to 'develop and use technology skills'. In their survey of employers on the most important technology skills accounting majors should possess, Cory and Pruske (2012) note that employers ranked spreadsheet software as the most critical accountingrelated technology, followed by word processing software, Windows proficiency, internet research skills, presentation software, and database software. Indeed, accounting students need to develop and utilize these skills as they maneuver through their coursework; it would be difficult to generate a professional-looking set of financial statements without the use of technology. 
In the field of accounting, in particular, this coursework knowledge or technical expertise is an absolute must. In his broad literature review of published studies on necessary skills for accounting graduates, de Villiers (2010) notes that not only do accounting students need to have strong technical knowledge, they also need many other skills to help them manage their lives and careers and be prepared for a commitment to lifelong learning. He grouped these additionally necessary skills into five categories: communication; problem-solving and thinking; leadership and team work; ethical and moral values; and self-management. De Villiers' (2010) category of selfmanagement includes a variety of related skills such as time management, organization, curiosity, continuous learning, and self-motivation. We have labeled a similar goal more generally to 'develop and use organizational skills'. These organizational skills will help students feel more confident as they create a study plan for their coursework, explore the profession, and ultimately search for a job.

The fourth objective in this most foundational perspective is to 'get involved on- and off-campus'. We include this objective as a foundational objective as researchers suggest these "educationally purposeful" activities contribute to a student's sense of belonging (on-campus) as well as contribute to their leadership development, decision-making abilities, and overall preparation for work (Kuh et al., 2006), further supporting our placement of this objective in the most foundational tier of the scorecard. Clearly accounting employers are not alone in demanding their new hires be well-rounded (de Villiers, 2010; Kavanagh and Drennan, 2008; Kuh et al., 2006).

\section{Student Professional Development Perspective}

Violette and Chene (2008) report that accounting firms are looking for students with leadership potential, strong interpersonal communication skills, and enthusiasm and motivation toward the profession. We include three objectives in our second perspective to capture these components:

\footnotetext{
- $\quad$ Enhance leadership skills;

- $\quad$ Enhance communication skills; and

- $\quad$ Explore the profession.
}

Certainly these 'soft' skills are included in de Villiers (2010) summary, as well. It was previously noted that leadership skills and communication skills accounted for two of his five categories of skills accounting graduates need for success. Further, he states, "Students need to develop not only sound interpersonal skills, but, more importantly, the skills to manage themselves and their careers, and they need to be prepared for a lifetime career of which lifelong learning is a part." If students are engaged in their educational experience, they will seek out opportunities to learn more about the profession they are working so hard to be a part of. These experiences, whether they be mentoring sessions with an alumnae or online research of a local firm's training programs, for example, will open students' eyes to the demands and challenges of this profession. This exploration should also reveal exciting career and growth opportunities within the field, leading to personal satisfaction that these professionals experience when getting to know their clients and helping them solve difficult reporting issues.

We included these three objectives within the second tier of the scorecard as many of the foundational goals are hypothesized to affect the achievement of the three goals at this tier, as described above. Further, the achievement of these goals has been found to positively affect objectives in the top tier.

\section{Employer/Graduate School Perspective}

In the concluding perspective of our student success scorecard we have included three objectives that should lead the way to a student's ultimate acceptance of a full-time position in the field or admittance into a graduate program of choice. The three objectives are:

- $\quad$ Gain real-world experience;

- $\quad$ Conduct job/graduate school searches; and

- $\quad$ Establish a plan for certification. 
Internships are an inherent part of many undergraduate accounting programs for a reason - they work (Siegel et al., 2010; Mauldin et al., 2006; McCombs and VanSycle, 1994). Students get an opportunity to apply their coursework knowledge and professional skills in a real-world setting, while both parties can test the 'fit' of the relationship within that particular organization and field before any longer-term commitment is made. 'Real-world experience' can be gained in other ways besides an internship, still. Many accounting firms offer summer leadership experiences and some courses provide real-world experiences to their students. Other students' existing jobs provide experiences that will be valued by accounting employers.

Students need to be engaged in the 'job search' process before they will be able to obtain an internship, let alone full-time employment. Many accounting students, instead of heading right into the job market, opt to attend graduate school immediately after graduation in order to obtain more specialized content knowledge in the field. Most undergraduate degree institutions provide career services to their students, offering a great deal of support in this job search or graduate school search effort. Diligent students who have been engaged in their educational experience should already possess many of the characteristics that accounting employers and graduate schools are looking for - namely technical skills (evidenced by grades) and soft skills (evidenced by their interaction in a variety of outside activities and ability to communicate those skills) (de Villiers, 2010; Violette and Chene, 2008; Kavanagh and Drennan, 2008). These components, as described earlier, are represented in the lower or more foundational tiers of the scorecard.

Many accounting students desire to provide further evidence of their competency in the accounting profession - outside of grades - via professional certification. A variety of internationally-recognized professional certifications are available to accounting graduates, depending on which aspect of the field the student desires to showcase this knowledge. Some common ones include:

- $\quad$ CPA (certified public accountant); the American Institute of CPA's (AICPA) boasts nearly 394,000 members in nearly 128 countries. (www.aicpa.org)

- $\quad$ CMA (certified management accountant); the Institute of Management Accountants (IMA) recognizes that there are more than 20,000 active CMA's in nearly 100 countries. (www.imanet.org)

- $\quad$ CIA (certified internal auditor); The Institute of Internal Auditors (IIA) recognizes that there are over 115,000 CIA's worldwide. (www.theiia.org)

- $\quad$ CISA (certified information systems auditor); previously known as the Information Systems Audit and Control Association (ISACA), ISACA, which now goes by its acronym only, boasts more than 110,000 constituents worldwide. ISACA governs four important certifications in the information technology area, including the CISA. (www.isaca.org)

Each of these designations requires an individual to pass a rigorous exam. It is usually in a student's best interest to consider taking the exam portion of the certification as close to completion of the undergraduate degree as possible, in order to benefit from proximity-effects (the more time that passes, the more knowledge the student will lose, if not practicing the material regularly). Additionally, since students are already in "study mode", they can benefit from the consistency of preparation and carry their diligent study habits into reviewing for the exam(s). Students are also interested in obtaining certification as soon as possible for one other reason - money. There is a great deal of evidence available suggesting that accountants possessing at least one certification earn significantly more than a comparable individual without the certification (Becker CPA Exam Review). Money does talk.

Once an individual passes the examination portion of the certification requirements, there is also an experience requirement that must be met before the individual can be a licensed practitioner in that area. For the CPA designation, for example, the minimum educational requirement is 150 -credits. Candidates typically fulfill this requirement with an undergraduate degree in accounting plus 30 additional credits, although some states require a master's degree. Additionally, one to two years of experience is then required for licensure (the specific education and experience requirements vary by jurisdiction). (www.aicpa.org) 
Because of the necessity for a student to have completed the earlier aspects of his or her educational experience prior to obtaining full-time employment in the field, attending graduate school, and/or obtaining certification, we have included these objectives in the top tier of the strategy map and scorecard, representing the culminating goals of a student's accounting education experience.

\section{Ethical Conduct Goal}

We include one final goal presented as an underlying objective to be woven through a student's entire educational experience and beyond: to 'act with integrity'. Not only is this a functional aspect of any professional's behavior, but also accreditation agencies and employers alike put ethical behavior at the forefront of their activities. Ethics components or courses are required in accredited accounting programs, and professional certification agencies require their members to sign off on and follow their specific professional codes of conduct. We anticipate that our inclusion of this objective will help students recognize the importance of ethical conduct throughout every facet of their college experience. (www.aacsb.edu; www.aicpa.org; www.imanet.org)

\section{Feedback Loop}

Inherent in all balanced scorecards is a feedback loop that allows a user to go back and evaluate the prior connections and performance objectives. Our scorecard allows students to do this, as well. We included a 'Year' column that highlights which year the student would typically focus on that activity. One will notice that many of the activities are ongoing, suggesting that students may make some progress in these areas but may need to come back to them for continued development. Take the communication skills objective, for example. Students may take a business writing course and attend a resume workshop in their first year, but may want or need to come back to it later to further develop those skills, particularly after having received mixed feedback from a recruiter in a mock interview session.

\section{Strategy Map}

Kaplan and Norton (2000) suggest that a strategy map (see Appendix B) be created in order to visually represent the connections between these goals. Each goal or objective is listed, and arrows are used to represent hypothesized directional-effects between the goals. The strategy map is linked to the balanced scorecard and is constructed with these same goals/objectives as the pillars in each perspective.

\section{USING THE SCORECARD AND STRATEGY MAP FOR ACCOUNTING STUDENT SUCCESS}

Our initial intention for this scorecard and strategy map is to enhance communication between accounting faculty and students for the purpose of increasing student engagement. Faculty advisors, when meeting with students just entering the accounting major, can share the key objectives in the strategy map while explaining to students that the connections between these key objectives are grounded in research. In other words, perhaps students will be more likely to 'buy in' to the importance of utilizing good study habits early in order to maintain good grades, as well as the importance of getting involved in outside activities, as well the importance of other soft skills - communication, leadership, etc. - if we can provide them with evidence in the form of a concise framework of what has worked for accounting students (and other students) in the past.

The balanced scorecard can be introduced to students during this initial advising session, as well, as a starting point for them to work toward the key objectives. Faculty members can explain that initiatives provide a list of possible ways to achieve each measure and it is certainly not necessary (and likely not possible) to achieve every measure or initiative on the scorecard. Still, these items represent possible means to the end, allowing students to better understand what they can do to help themselves. While the scorecard may appear overwhelming to students at first, proper communication from faculty advisors can help them focus on a handful of objectives at a time, thus helping them make good progress toward their goals. Further, students should see that there is a great deal of flexibility in this scorecard in terms of reaching the individual objectives. There are a number of initiatives identified (and the identified initiatives are by no means an exhaustive list) that students can try as they work toward 
the target measures and ultimate objectives. Students can each carve their own unique paths through this scorecard in order to enhance their existing skill sets while developing new ones.

\section{CONCLUSION}

Since student engagement is related to a number of positive outcomes, including higher grades, satisfaction with their educational experience, and ultimately employment in their field of study (Kuh et al., 2006), we believe that this communication tool, or set of tools, will help accounting students be more engaged. Student-faculty interactions also have an impact on student engagement, particularly when faculty encourage students to put more effort toward other "educationally purposeful activities" during college (Kuh et al., 2006). If faculty can encourage students to consider these multiple aspects of their educational experience as interconnected and important, we expect student engagement will become stronger, leading to greater and/or wider success for these students.

Wessels and Sumner (2014) also recognize the importance of accounting student engagement in developing job search skills. They describe the integrated approach used in their university, where professional development activities are required as components of individual required courses. They report limited data to suggest that this program is making a difference. We believe that our balanced scorecard approach to student engagement allows a great deal of flexibility to all students, allowing them to see what has worked for students in the past, while not forcing any student to take on activities they are not ready for. Further, the discussions likely to take place between students and faculty while going through this journey will likely enhance a stronger connection between these two parties, perhaps encouraging even more frequent contact throughout the students' educational experience. This, alone, could be an important step toward success for these majors.

\section{FUTURE WORK/EXTENSIONS}

While we have created this scorecard and strategy map for accounting students in particular, this set of tools could be adapted to serve students in virtually any major program of study, by adjusting the objectives and specific initiatives, measures, etc. In addition to extending this set of tools to a broader audience, we can collect data on the given scorecard and strategy map in order to test the hypothesized relationships empirically. This data will be invaluable as we move forward, considering necessary adjustments to the path due to changes in the environment.

\section{AUTHOR INFORMATION}

Amy Fredin is an Associate Professor in the Department of Accounting at St. Cloud State University where she teaches primarily in the Cost/Managerial Accounting area both at the undergraduate and graduate level. Amy holds a $\mathrm{PhD}$ in Accounting from the University of Nebraska, Lincoln, and has since published articles in the areas of whistleblowing and the balanced scorecard, along with a cost accounting teaching case. She is an active member of the Central MN Chapter of the IMA, and has published in Strategic Finance, Ethics \& Behavior, Management Research Review, and Journal of Business Cases and Applications. E-mail: ajfredin@ stcloudstate.edu

Peter Fuchsteiner is an Assistant Professor of Accounting at St Cloud State University. Peter obtained his Juris Doctorate from William Mitchell College of Law in St Paul, Minnesota. He teaches courses in federal taxation of businesses and individuals as well as financial reporting and managerial accounting. His research interests include managerial accounting and federal and state taxation. His research has appeared in State Bar Association publications as well as Lorman Educational publications. E-mail: pjfuchsteiner@stcloudstate.edu

Kris Portz is a professor of accounting at St. Cloud State University. She holds a PhD in accounting from the University of Nebraska - Lincoln and teaches courses in intermediate accounting and international accounting. Her research interests are in managerial accounting, international accounting, and accounting education. Her research has appeared in American Journal of Business, Journal of International Business Discipline, CMA Management Journal, and The Review of Business Information Systems. E-mail: ksportz@ stcloudstate.edu (corresponding author) 


\section{REFERENCES}

1. Andrews, J., \& Higson, H. (2008). Graduate employability, 'soft skills' versus 'hard' business knowledge: A European Study. Higher Education in Europe (Special Issue) , 33 (4), 411-422.

2. Arquero-Montano, J., Donoso, J., Hassall, T., \& Joyce, J. (2001). Vocational skills in the accounting professional profile: the Chartered Institute of Management Accountants (CIMA) employer's opinion. Accounting Education: An International Journal , 10 (3), 299-313.

3. Beard, D. (2009, May/June). Successful applications of the Balanced Scorecard in higher education. Journal of Education for Business, 275-282.

4. Becker CPA Exam Review. (n.d.). Retrieved March 20, 2014, from Robert Half 2008 Salary Guide: http://www.cpaexam.com/certified-public-accountant-salary

5. Bieker, T. (2003). Sustainability management with the Balanced Scorecard. Conference Proceedings of the 5th International Summer Academy on Technology Studies (pp. 17-34). Deutschlandsberg, Austria: U. eds. Corporate Sustainability.

6. Bowen, W., Chinqos, M., \& McPherson, M. (2009). Crossing the Finish Line. Princeton University PRess.

7. Carey, K. (May 2004). A Matter of Degrees: Improving Graduation Rates in Four-Year Colleges and Universities. Washington, DC: Education Trust.

8. Cory, S., \& Pruske, K. (2012, February). Necessary skills for accounting graduates: An exploratory study to determine what the profession wants. ASBBS Annual Conference, (pp. 208-218). Las Vegas.

9. Cullen, J., Joyce, J., Hassall, T., \& Broadbent, M. (2003). Quality in higher education: From monitoring to management. Quality Assurance in Education, 11 (1), 5-14.

10. de Villliers, R. (2010). The incorporation of soft skills into accounting curricula: Preparing graduates for their unpredictable futures. Meditari Accountancy Research, 18 (2), 1-22.

11. Fallows, S., \& Stevens, C. (2000). Building employability skills into the higher education curriculum: A university wide initiative. Education and Training , 42 (2/3), 75-83.

12. Gammie, B., \& Gammie, E. (2002). Personal skills development in the accounting curriculum. Accounting Education: An International Journal , 11 (1), 63-78.

13. Hassel, H., \& Laurey, J. (2005). The Dea(r)th of Student Responsibility. College Teaching , 53 (1), 2-13.

14. Hughes II, K. E., \& Pate, G. (2013). Moving Beyond Student Ratings: A Balanced Scorecard Approach for Evaluating Teaching Performance. Issue in Accounting Education, 28 (1), 49-75.

15. Kaplan, R., \& Norton, D. (2000). Having trouble with your strategy? Then map it. Harvard Business Review (September-October), 167-176.

16. Kaplan, R., \& Norton, D. (1992). The Balanced Scorecard: Measures that drive performance. Harvard Business Review (January - February), 71-79.

17. Kaplan, R., \& Norton, D. (2001). Transforming the Balanced Scorecard from performance measurement to strategic management, Part II. Accounting Horizons , 15 (1), 87-104.

18. Karathanos, D., \& Karathanos, P. (2005). Applying the Balanced Scorecard to education. Journal Of Education for Business , 80 (4), 222-230.

19. Kavanagh, M., \& Drennan, L. (2008). What skills and attributes does an accounting graduate need? Evidence from student perceptions and employer expectations. Accounting and Finance, 48, 279-300.

20. Knapp, L., Kelly-Reid, J., \& Whitmore, R. (2006). Enrollment in Postsecondary Institutions, Fall 2004, Graduation Rates, 1998 \& 2001 Cohorts; and Financial Statistics, Fiscal Year 2004 (NCES 2006-155). Retrieved from U.S. Department of Education. Washington, DC: National Center for Education Statistics: http://nces.ed.gov/pubsearch/pubsinfo.asp?pubid-2006155 (accessed March 14, 2006)

21. Kuh, G., Kinzie, J., Buckley, J., Bridges, B., \& Hayek, J. (July 2006). What Matters to Student Success: A Review of the Literature. Commissioned Report for the National Symposium on Postsecondary Student Success: Spearheading a Dialog on Student Success.

22. Mauldin, S., Zachry, S., \& Morris, J. (2006). Does student work experience affect CPA firm recruiting decisoins? The Accounting Educators Journal, 16, 41-51.

23. McCarthy, M., \& Kuh, G. (2006). Are Students Ready for College? What Student Engagement. Phi Delta Kappan , 87(9), 664-669.

24. McCombs, G., \& VanSycle, L. (1994). Accounting internships: A win-win arrangement. The National Public Accountant , 39 (5), 21-23. 
25. Michalska, J. (2005). The usage of the Balanced Scorecard for the estimation of the enterprise's effectiveness. Journal of Materials Processing Technology , 162-163, 751-758.

26. National Survey of Student Engagement (NSSE). (2005). Student Engagement: Exploring Different Dimensions of Student Engagement. Bloomington, IN: Indiana University Center for Postsecondary Research.

27. Niven, P. (2003). Balanced Scorecard: Step by Step for Government and Nonprofit Agencies. Hoboken, NJ: John Wiley \& Sons.

28. Pascarella, E., \& Terenzini, P. (2005). How College Affects Students: A Third Decade of Research. San Francisco: Jossey-Bass.

29. Scarpati, S., \& Johnson, P. (2012). Teaching and advising a new generation of accounting students. The CPA Journal , 82 (8), 14-17.

30. Siegel, P., Blackwood, B., \& Landy, S. (2010, May). Tax professional internships and subsequent professional performance. American Journal of Business Education, 51-59.

31. Storey, A. (2002). Performance management in schools: Could the Balanced Scorecard help? School Leadership Management, 22 (3), 321-338.

32. Violette, G., \& Chene, D. (2008). Campus recruiting: What local and regional accounting firms look for in new hires. The CPA Journal, 78 (12), 66-68.

33. Wessels, S., \& Sumner, D. (2014). Integrating career development into the accounting curriculum. American Journal of Business Education , 7 (1), 21-30. 


\section{APPENDIX A}

\section{Balanced Scorecard For Accounting Student Success}

\begin{tabular}{|c|c|c|c|c|c|}
\hline & & & $\begin{array}{r}\text { Overall Visic } \\
\text { To earn a degree an }\end{array}$ & $\begin{array}{l}\text { on and Strategy } \\
\text { d get a well-suited job }\end{array}$ & \\
\hline & & To achiev & $\begin{array}{l}\text { Employer/Graduat } \\
\text { your vision, how yo }\end{array}$ & $\begin{array}{l}\text { School Perspective } \\
\text { u should appear to the employer? }\end{array}$ & \\
\hline Objectives & Year & Measures & Targets & Initiatives & Student Progress \\
\hline Real World Experience & & & & & \\
\hline $\begin{array}{l}\text { a. Gain real work experience } \\
\text { that prepares you for entry into }\end{array}$ & $2-3$ & $\begin{array}{l}\text { Number of internships } \\
\text { applied for }\end{array}$ & $5+$ & $\begin{array}{l}\text { - Participate in a summer leadership program } \\
\text { - Get an internship }\end{array}$ & \\
\hline the accounting profession & & $\begin{array}{l}\text { Number of intern hours } \\
\text { on the job }\end{array}$ & $\begin{array}{l}40+\text { hours per } \\
\text { week (full-time } \\
\text { internship) }\end{array}$ & $\begin{array}{l}\text { - Participate in the VITA program } \\
\text { - Get a college job with relevancy to accounting } \\
\text { - Become the treasurer of a student or community organization }\end{array}$ & \\
\hline & & Number of VITA hours & $\begin{array}{c}3+\text { hours per week } \\
\text { (VITA) }\end{array}$ & & \\
\hline Job Search & & & & & \\
\hline $\begin{array}{l}\text { a. Effectively search for a job } \\
\text { and land a position }\end{array}$ & $2-3$ & $\begin{array}{l}\text { Number of locations } \\
\text { resume is posted }\end{array}$ & $2+$ & $\begin{array}{l}\text { - Finalize resume. Be sure to emphasize organizational, leadership, } \\
\text { communication, and analytical skills you have acquired. }\end{array}$ & \\
\hline & & $\begin{array}{l}\text { Number of jobs applied } \\
\text { for }\end{array}$ & $5+$ & $\begin{array}{l}\text { - Attend an interviewing seminar and practice interviewing } \\
\text { - Finalize references and get recommendation letters if necessary } \\
\text { - Join Linked In }\end{array}$ & \\
\hline Plan for Certification & & & & & \\
\hline $\begin{array}{ll}\text { a. } & \text { Establish process to achieve } \\
\text { professional certification (if } \\
\text { desired) }\end{array}$ & 3 & $\begin{array}{l}\text { Number of certification } \\
\text { exams registered for }\end{array}$ & $1+$ & $\begin{array}{l}\text { - Explore options (i.e. CPA, CMA, CIA, CISA, etc.), minimum } \\
\text { requirements to sit for exam and exam coverage, including } \\
\text { academic courses and, career paths each is most appropriate for } \\
\text { - Determine appropriate review course provider and delivery method } \\
\text { - Align exam coverage with your academic career path }\end{array}$ & \\
\hline
\end{tabular}




\begin{tabular}{|c|c|c|c|c|c|}
\hline \multicolumn{6}{|c|}{$\begin{array}{l}\text { Student Professional Development Perspective } \\
\text { achieve your vision, what must you do to prepare for the profession? }\end{array}$} \\
\hline Objectives & Year & Measures & Targets & Initiatives & Student Progress \\
\hline \multicolumn{6}{|l|}{ Enhance Leadership Skills } \\
\hline a. Develop leadership skills & $2-3$ & $\begin{array}{l}\text { Number of leadership } \\
\text { activities }\end{array}$ & $1+$ & $\begin{array}{l}\text { - Take on a leadership role in a student organization, at work, or in a } \\
\text { class project } \\
\text { - Look for opportunities on campus or at your job to develop your } \\
\text { leadership skills }\end{array}$ & \\
\hline \multicolumn{6}{|l|}{ Enhance Communication Skills } \\
\hline $\begin{array}{l}\text { a. Develop strong written } \\
\text { communication skills }\end{array}$ & $1-3$ & $\begin{array}{l}\text { Number of writing } \\
\text { courses }\end{array}$ & $1+$ & $\begin{array}{l}\text { - Take a business communications class } \\
\text { - Take a creative writing class } \\
\text { - Attend a resume workshop and get your resume ready } \\
\text { - Write for the school paper } \\
\text { - Enter into the AICPA accounting competition } \\
\text { - Look for other opportunities to develop your written communication } \\
\text { skills at your job. } \\
\text { - Utilize the writing resource center on campus } \\
\text { - Read (business articles, newspapers, blogs, websites) }\end{array}$ & \\
\hline $\begin{array}{l}\text { b. Develop strong oral } \\
\text { communication skills }\end{array}$ & $1-3$ & $\begin{array}{l}\text { Number of oral } \\
\text { communication courses }\end{array}$ & $1+$ & $\begin{array}{l}\text { - Take a public speaking class or other oral communication course } \\
\text { - Seek public speaking opportunities } \\
\text { - Participate in a mock interview } \\
\text { - Look for opportunities to develop your oral communication skills at } \\
\text { - your job } \\
\text { - Participate in class - ask/answer questions } \\
\text { - Get comfortable visiting with recruiters at networking events }\end{array}$ & \\
\hline \multicolumn{6}{|l|}{ Explore Profession } \\
\hline \multirow[b]{2}{*}{$\begin{array}{l}\text { a. Engage in career planning } \\
\text { and networking to increase } \\
\text { understanding of the profession, } \\
\text { make contacts, and show } \\
\text { motivation towards the } \\
\text { profession }\end{array}$} & \multirow[t]{2}{*}{$1-3$} & Shadow hours & $5+($ yr 2-3) & \multirow[b]{2}{*}{$\begin{array}{l}\text { - Develop personal career goals } \\
\text { - Explore resources at campus career center } \\
\text { - Talk with your advisor on career planning } \\
\text { - Introduce yourself to your professors so they know who you are and } \\
\text { can provide you with career advice } \\
\text { - Attend career fairs to explore profession and network } \\
\text { - Perform internet searches on facets of the profession (i.e. "'Become a } \\
\text { CPA" on the AICPA website) } \\
\text { - Perform internet searches on firms that recruit on campus } \\
\text { - Shadow an accountant, set up information interviews, and tour firms } \\
\text { - Become a student member of a professional organization such as } \\
\text { IMA or the AICPA } \\
\text { - Become an active member of a business student organization (an } \\
\text { accounting focus is highly recommended) that have relevant } \\
\text { networking opportunities } \\
\text { - Attend firm sponsored socials } \\
\text { - Connect with the local Chamber of Commerce }\end{array}$} & \\
\hline & & $\begin{array}{l}\text { Research Hours } \\
\text { Number of networking } \\
\text { events attended }\end{array}$ & $\begin{array}{l}10+(\mathrm{yr} 1-3) \\
2+(\mathrm{yr} 1) \\
4+(\mathrm{yr} 2) \\
4+(\mathrm{yr} 3) \\
4+\end{array}$ & & \\
\hline
\end{tabular}




\begin{tabular}{|c|c|c|c|c|c|}
\hline \multicolumn{6}{|c|}{$\begin{array}{c}\text { Learning And Growth Perspective } \\
\text { To achieve your vision, how will you sustain your ability to change and improve? }\end{array}$} \\
\hline Objectives & Year & Measures & Targets & Initiatives & Student Progress \\
\hline \multicolumn{6}{|l|}{ Academic Goalposts } \\
\hline $\begin{array}{l}\text { a. Successfully complete the } \\
\text { foundational courses in the major } \\
\text { (Intermediates, Cost, and } \\
\text { Systems) }\end{array}$ & 1 & Grade & $3.0+$ & $\begin{array}{l}\text { - Utilize good study habits early } \\
\text { - Find study partners } \\
\text { - Understand time management and time commitment of an accounting } \\
\text { - } \text { Urogram } \\
\text { - Use these courses to determine if accounting is the right major } \\
\text { - Connect coursework to the profession }\end{array}$ & \\
\hline $\begin{array}{l}\text { b. Successfully complete the tax } \\
\text { and audit sequence }\end{array}$ & $2-3$ & Grade & $3.0+$ & - Generally complete these courses before interning & \\
\hline $\begin{array}{l}\text { c. Successfully complete your } \\
\text { accounting electives }\end{array}$ & $2-3$ & Grade & $3.0+$ & $\begin{array}{l}\text { - Choose electives that align with your career goals } \\
\text { - Choose electives that provide the best CPA exam preparation } \\
\text { - Choose electives that will increase your understanding of global } \\
\text { issues and develop some IFRS competency } \\
\text { - Make a plan for completing academic requirements for certification } \\
\text { (i.e. } 150 \text { credits hours for CPA licensure) } \\
\text { - Keep current on what is happening with the SEC, FASB, IASB, and } \\
\text { PCAOB }\end{array}$ & \\
\hline \multicolumn{6}{|l|}{ Technology Skills } \\
\hline \multirow{2}{*}{$\begin{array}{l}\text { a. Develop skills in Microsoft } \\
\text { Office (Windows, Excel, Word, } \\
\text { PowerPoint, Access, Outlook) }\end{array}$} & $1-3$ & $\begin{array}{l}\text { Number of Technology } \\
\text { Workshops Completed }\end{array}$ & $1+$ per semester & \multirow{2}{*}{$\begin{array}{l}\text { - Complete AIS course } \\
\text { - Take IS electives } \\
\text { - Attend on campus technology workshops } \\
\text { - Participate in technology webinars } \\
\text { - Complete Excel Certification }\end{array}$} & \\
\hline & & $\begin{array}{l}\text { Number of IS/AIS } \\
\text { courses }\end{array}$ & $1+$ & & \\
\hline $\begin{array}{l}\text { b. Appropriately use social } \\
\text { networking tools }\end{array}$ & $1-3$ & $\begin{array}{l}\text { Number of social media } \\
\text { tools used }\end{array}$ & $1+$ & $\begin{array}{l}\text { - Follow relevant Twitter accounts, blogs, listservs } \\
\text { - Become familiar with LinkedIn }\end{array}$ & \\
\hline \multicolumn{6}{|l|}{ Organization Skills } \\
\hline a. Develop effective study habits & 1 & Weekly Study Hours & $\begin{array}{l}45 \text { minutes }+ \text { per } \\
\text { day, per class }\end{array}$ & $\begin{array}{l}\text { Class Preparation: } \\
\text { - Read material before class lecture } \\
\text { - Complete assigned homework } \\
\text { In Class Engagement } \\
\text { - Take notes } \\
\text { - Ask questions } \\
\text { Review after Class: } \\
\text { - Review homework covered in class } \\
\text { - Re-read material for better understanding } \\
\text { - Practice, practice, practice } \\
\text { - Get help from professors } \\
\text { - Visit the tutor lab }\end{array}$ & \\
\hline
\end{tabular}




\begin{tabular}{|c|c|c|c|c|}
\hline $\begin{array}{l}\text { b. Understand the time } \\
\text { commitment of an accounting }\end{array}$ & 1 & Weekly Study Hours & $\begin{array}{l}45 \text { minutes }+ \text { per } \\
\text { day, per class }\end{array}$ & $\begin{array}{l}\text { - Prepare a personal weekly time budget - map out your schedule and } \\
\text { set priorities }\end{array}$ \\
\hline $\begin{array}{l}\text { major and develop your time } \\
\text { management skills }\end{array}$ & & Work Hours & $\begin{array}{l}<20 \text { hours } \\
\text { per week }\end{array}$ & $\begin{array}{l}\text { - Prepare weekly study plans and set goals on what homework needs to } \\
\text { be completed each week } \\
\text { - Attend a time management seminar or webinar } \\
\text { - Use available campus resources on study skills (i.e. study center) } \\
\text { - Get enough sleep } \\
\text { - Maintain a healthy lifestyle; stay active and take care or yourself }\end{array}$ \\
\hline Campus and Community Involven & & & & \\
\hline a. Get involved on campus & $1-3$ & $\begin{array}{l}\text { Number of } \\
\text { Memberships in student } \\
\text { organizations }\end{array}$ & $1+$ & $\begin{array}{l}\text { - Explore student organizations on campus } \\
\text { - Join student organization (s) of interest and/or relevance } \\
\text { - Participate in varsity athletics, club sports or intramurals }\end{array}$ \\
\hline & & $\begin{array}{l}\text { Number of other } \\
\text { activities }\end{array}$ & $1+$ per semester & $\begin{array}{l}\text { - Pursue other hobbies or interests } \\
\text { - Participate in a study abroad experience }\end{array}$ \\
\hline b. Get involved in the community & $1-3$ & $\begin{array}{l}\text { Number of Volunteer } \\
\text { Hours }\end{array}$ & $\begin{array}{c}5+\text { per } \\
\text { semester }\end{array}$ & $\begin{array}{l}\text { - Explore volunteer opportunities on campus or through student } \\
\text { organizations } \\
\text { - Explore volunteer opportunities in the community }\end{array}$ \\
\hline Ethical Conduct & & & & \\
\hline a. Develop ethical awareness & $1-3$ & Grade in ethics course & $3.0+$ & $\begin{array}{l}\text { - Become familiar with an ethical framework for decision making } \\
\text { - Relate general ethics principles to everyday situations } \\
\text { - Extend general ethics principles to hypothetical business scenarios } \\
\text { - Attend ethics seminars or other ethic sponsored programs on campus }\end{array}$ \\
\hline $\begin{array}{l}\text { b. Act with integrity in all } \\
\text { endeavors }\end{array}$ & $1-3$ & $\begin{array}{l}\text { Clean record } \\
\text { Number of times } \\
\text { engaged in academic } \\
\text { dishonesty }\end{array}$ & $\begin{array}{c}100 \% \\
0\end{array}$ & $\begin{array}{l}\text { - Establish in individual process for dealing with academic dishonesty } \\
\text { temptations. Exercise the "Golden Rule" in personal and } \\
\text { professional behavior } \\
\text { - Avoid any and all academic dishonesty incidences } \\
\text { - Keep out record clean (important for professional certification) }\end{array}$ \\
\hline
\end{tabular}




\section{APPENDIX B}

Strategy Map For Accounting Student Success

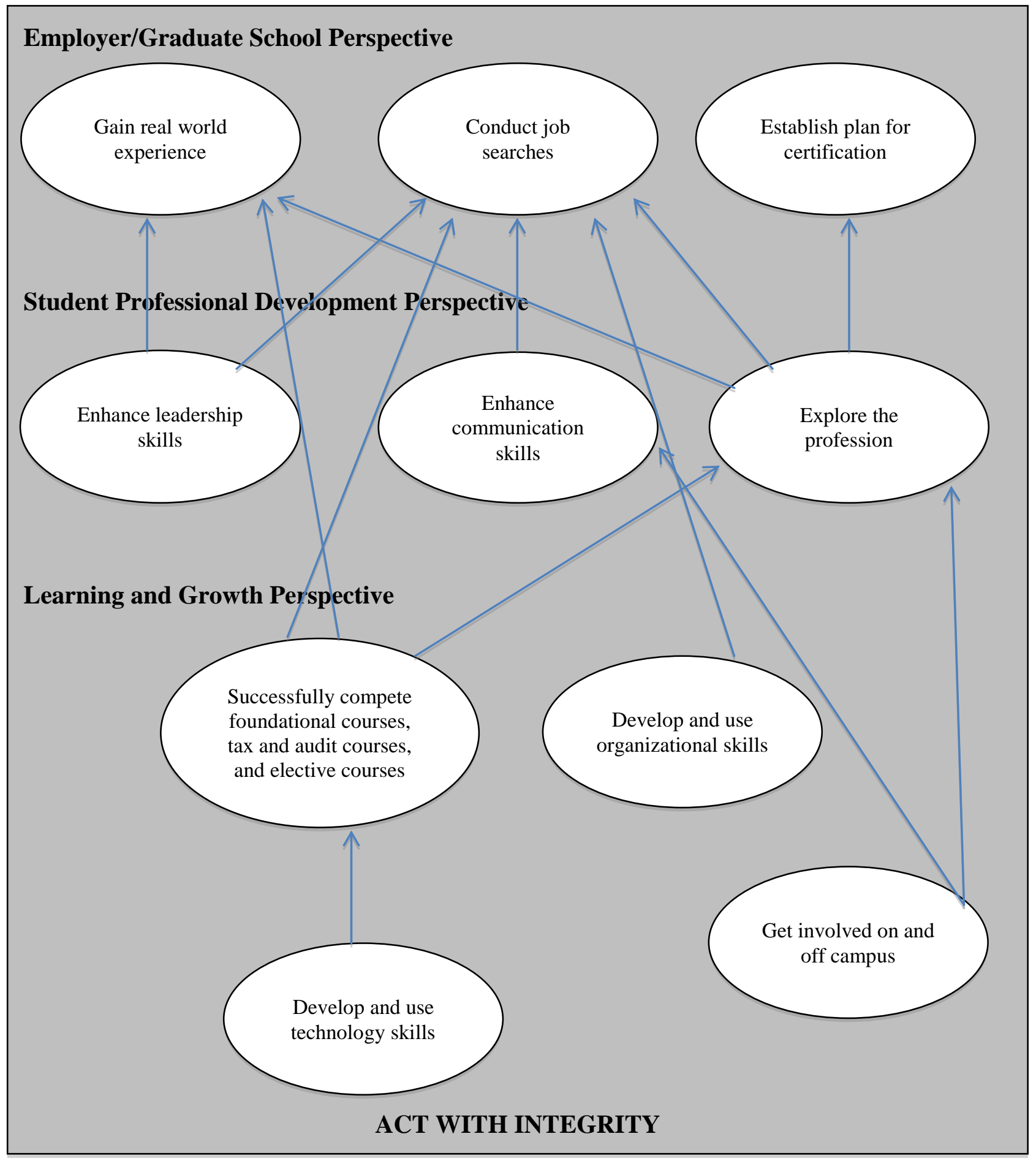

